\title{
Relative abundance and diet composition of Chacoan cavies in relation to range condition
}

\author{
VICTORIA R. ROSATI AND ENRIQUE H. BUCHER
}

\begin{abstract}
Authors are teaching assistant and director at Centro de Zoologia Aplicada, Universidad Nacional de Cordoba. C.C. 122 5000 Córdoba. Argentina.
\end{abstract}

\begin{abstract}
The relative abundance and dietary botanical composition of the Chacoan cavy (Pediolagus salinicola) was studied on sites of very good, good, and poor range condition in the Western Chaco, Argentina. Pellet count data showed that Chacoan cavy densities varied $(P<0.001)$ among these areas. In both seasons, the highest number of pellets was found in the area of poor condition. This area was characterized by an absence of grasses, dense cover of a creeping fern (Selaginella sellowii), thorny shrubs and a scarcity of dicot herbs. In contrast, a decrease $(P<0.05)$ in Chacoan cavy densities was found in the good and very good range condition areas, coincident with the increase of grass and forb cover. Fecal analysis showed that Chacoan cavy diets were greatly influenced by the amount of forage available, which varied according to the condition of the rangeland. Forbs were the main forage class consumed in all range conditions, but the species composition differed among condition classes. For example, several species of dicot forbs were consumed in areas of very good and good range condition, but Selaginella sellowii was the main dietary forb when the range condition was poor. We concluded that range condition affected the relative abundance and diet of Chacoan cavies of Western Chaco, Argentina. High Chacoan cavy density should be considered as an indicator of vegetation depletion caused by other factors rather than a primary cause of savanna degradation.
\end{abstract}

Key Words: Pediolagus salinicola, Chaco, diet, range condition, relative abundance

The Chacoan cavy (Pediolagus salinicola) is a rabbit-like rodent endemic to Western Chaco, ranging from western Paraguay to central western Argentina (Cabrera and Yepes 1940). The Chacoan cavy prefers open, semi-arid woodland and shrubland (Cabrera and Yepes 1940, Mares et al. 1989). It is diurnal and does not dig burrows, sheltering instead in hollow or rotting logs, or burrows dug by other animals. Besides general descrip-

The Consejo Nacional de Investigaciones Cientificas y Técnicas of Argentina provided funds through post-graduate scholarships to V.R.R. and a research grant to E.H.B. (PID 3908102/85-88). We thank Campos del Norte S.A. and Salta Forestal S.A. for allowing us the use of their properties for fieldwork, C.A. Saravia Toledo for his constant support, M. Nores and J.L. Maron for comments on the manuscript and $A$. Snyder for improving the English language.

Manuscript accepted 5 Feb. 1995. tions of its diet (Rosati and Bucher 1992), little is known about its ecological requirements.

The landscape of Western Chaco is dominated by tall xerophyllous subtropical woodland with patches of grasslands (Sarmiento 1972). Most of the economy of the region is based on livestock, timber, and charcoal. As in other tropical savannas, grazing by livestock and clearing of trees for harvesting has resulted in a rapid degradation of the original vegetation. Now, most of the Western Chaco grassland has been eliminated and replaced by a dense thornscrub that covers millions of hectares (Morello and Saravia Toledo 1959).

Chacoan cavies are common herbivores in the eastern part of Salta province. In this region, high densities of these rodents are present in some areas but not others. Preliminary observations suggested that the Chacoan cavy tends to increase in overgrazed areas (Bucher 1982). At high densities the Chacoan cavy could destroy the seedlings and young plants of trees, preventing the regeneration of the dominant trees (Saravia Toledo 1987). The purpose of our research was to study the influence of range condition on: (1) the abundance of the Chacoan cavies; and (2) the botanical composition of Chacoan cavies' diets on a seasonal basis.

\section{Study Area and Methods}

Field work was conducted near Joaquin V. Gonzalez, Salta Province (Argentina) at $25^{\circ} 05^{\prime} \mathrm{S}, 64^{\circ} 10^{\prime} \mathrm{W}$ and an elevation of $378 \mathrm{~m}$. The Western Chaco of Argentina is a vast semi-arid region extending from the Pilcomayo River in the north to central Argentina on the south, and from a $700 \mathrm{~mm}$ rainfall contact line in central Chaco up to the foot of the western Sierras. Plant communities are composed of 2 dominant trees, quebracho colorado (Schinopsis quebracho-colorado) and quebracho blanco (Aspidosperma quebracho-blanco). Understories are generally dominated by garabato (Acacia praecox), algarrobos (Prosopis spp.), sinqui (Mimosa detinens) and talilla (Celtis pallida). The common genera grasses are Setaria, Trichloris, Aristida and Gouinia. The predominant forbs include several species of Malvaceae. Cacti and terrestrial and epiphytic bromeliads (Bromelia serra and $B$. hieronymii, Tillandsia spp.) are abundant. In overgrazed areas, the ground is covered mostly by a creeping pteridophyte (Selaginella sellowii) (Morello and Saravia Toledo 1959). 
The region has 2 distinct climatic seasons: a humid, hot summer (November-April) and a dry, cool winter (May-October). The annual average temperature is $22.3^{\circ} \mathrm{C}$, with a mean maximum of $36.1^{\circ} \mathrm{C}$ during the warmest month (January) and a mean minimum of $7.0^{\circ} \mathrm{C}$ during the coolest month (July). Annual rainfall averages $500 \mathrm{~mm}$, concentrated between November and April (Galmarini and Raffo del Campo 1964).

We selected 3 study sites with different range conditions (Saravia Toledo 1987) resulting from grazing by livestock: (1) very good range condition with more than 25 years of rest-rotation grazing management; (2) good range condition with 10 years of rest-rotation management; and (3) poor condition with a long history of overgrazing. Sites 1 and 2 were at Campos del Norte Ranch and Site 3 at Salta Forestal S.A. The study was conducted from August 1986 to March 1988, with samples taken from both the wet season and dry season. In each site we selected a sampling area of approximately 1 square kilometer.

Vegetation was sampled for each range type along 2-6 randomly established $100-\mathrm{m}$ transects. Plants and bare ground cover were estimated by a point-intercept method (USDA Forest Service 1970). Measurements were made by visual examination of points placed at 2-m intervals along each transect to a height of $1 \mathrm{~m}$. Percent cover of each plant species within a study area was calculated by dividing the number of points falling on a given species by the total number of points sampled. Information on the palatability of different plant species to livestock was taken from Morello and Saravia Toledo (1959). Pellet counts were used to assess the relative abundance of Chacoan cavies (Litvaitis et al. 1985). Data were obtained from 90 circular $0.28 \mathrm{~m}^{2}$ plots placed randomly along three $100-\mathrm{m}$ sample lines established at each site. Fecal pellets were counted within each plot.

Diet composition of Chacoan cavies was studied by microscopic analysis of feces (Sparks and Malechek 1968). Fresh fecal pellets were collected within the study sites. Two replicate collections of fecal pellets were made in August 1986 and October 1987 (dry season), and in April 1987 and March 1988 (wet season). A composite sample for each collection consisted of 30-50 pellets collected at random from each study site. On the very good condition area, we collected only 1 composite sample for each season of each year because of the low density of Chacoan cavies. Each composite sample was dried, ground, and passed through a 1-mm mesh sieves to insure thorough mixing (Hansen et al. 1971). We cleared the samples using the technique of Williams (1969). Five microscope slides were made for each sample and 50 microscope fields per slide were systematically examined. Each microscope field contained an average of 3 to 5 identifiable fragments when viewed at $100 \times$ magnification (Johnson et al. 1983). Food items were identified by comparing fecal material with a reference collection that included most of the plant species present in the area (Rosati 1991). Only epidermal plant fragments were used as evidence for the presence of a species. Data taken from the slides were expressed as percent relative frequency of occurrence following Holechek and Gross (1982).

Similarity of diets was calculated using Kulcyznski's formula (Oosting 1956). The similarity index represented the percentage of 2 diets that were identical. Statistical tests followed Zar (1984). Data were transformed if variances were heterogenous as determined by Barlett's test. Arcsin transformations were performed on the percentage data and square root transformation on the pellets counts data. Analysis of variance and the Scheffe procedure were used to test for significant differences $(P \leq 0.05$ among means).

\section{Results}

\section{Range Condition}

Grasses showed the highest cover on very good condition range, mainly during the wet season (Table 1). Several species of Aristida, Chloris, Eragrostis, Gouinia, Pappophorum, Paspalum and Trichloris comprised over the $75 \%$ of the total grass cover. Dicot forb cover was also greater on the very good condition area than on either the good and poor condition sites. Frequent forb species were perennials including Baccharis flexuosa, Justicia squarrosa, and several species of Malvaceae. Shrub cover was lower on the very good range condition than in the other areas. Shrub species that occur mainly in light grazed areas, such as Aloysia gratissima, were common. The coverage of Selaginella sellowii was not important.

\begin{tabular}{|c|c|c|c|c|c|c|}
\hline & \multicolumn{2}{|c|}{ Very good } & \multicolumn{2}{|c|}{ Good } & \multicolumn{2}{|c|}{ Poor } \\
\hline & Wet & Dry & $\overline{\text { Wet }}$ & $\overline{\text { Dry }}$ & Wet & $\overline{\text { Dry }}$ \\
\hline & \multicolumn{6}{|c|}{ 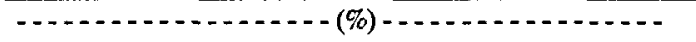 } \\
\hline Dicot forbs & $\begin{array}{c}48 \\
(+13.4)\end{array}$ & $\begin{array}{c}16 \\
( \pm 12.6)\end{array}$ & $\begin{array}{l}25 \\
( \pm 7.4)\end{array}$ & $\begin{array}{c}4 \\
( \pm 5.3)\end{array}$ & $\begin{array}{c}2 \\
( \pm 3.2)\end{array}$ & 0 \\
\hline Grasses & $\begin{array}{c}70 \\
( \pm 21.7)\end{array}$ & $\begin{array}{l}25 \\
( \pm 9.41)\end{array}$ & $\begin{array}{c}27 \\
( \pm 16.2)\end{array}$ & $\begin{array}{c}12 \\
( \pm 21.8)\end{array}$ & 0 & 0 \\
\hline Shrubs & $\begin{array}{c}14 \\
( \pm 6)\end{array}$ & $\begin{array}{c}16 \\
( \pm 11.3)\end{array}$ & $\begin{array}{c}59 \\
( \pm 30.2)\end{array}$ & $\begin{array}{c}30 \\
(+12.2)\end{array}$ & $\begin{array}{l}50 \\
(26.2)\end{array}$ & $\begin{array}{c}27 \\
( \pm 14.1)\end{array}$ \\
\hline S. Sellowii & $\begin{array}{r}1.5 \\
( \pm 1.5)\end{array}$ & $\begin{array}{c}2 \\
(+2.2)\end{array}$ & $\mathrm{T}$ & $\mathrm{T}$ & $\begin{array}{c}69 \\
( \pm 14.3)\end{array}$ & $\begin{array}{c}67 \\
( \pm 14)\end{array}$ \\
\hline Bare ground & $\begin{array}{c}22 \\
( \pm 10.2)\end{array}$ & $\begin{array}{c}29 \\
( \pm 19.9)\end{array}$ & $\begin{array}{c}20 \\
( \pm 10.5)\end{array}$ & $\begin{array}{c}5 \\
( \pm 5.2)\end{array}$ & $\begin{array}{c}31 \\
( \pm 14.3)\end{array}$ & $\begin{array}{c}33 \\
( \pm 14)\end{array}$ \\
\hline $\begin{array}{l}\text { Grazing } \\
\text { management }\end{array}$ & \multicolumn{2}{|c|}{ Rest-rotation } & \multicolumn{2}{|c|}{ Rest-rotation } & \multicolumn{2}{|c|}{$\begin{array}{c}\text { Overgrazing } \\
\text { No management }\end{array}$} \\
\hline
\end{tabular}

$T=$ Trace

On the good condition area, shrubs were dominant during both seasons (Table 1). Atamisqui (Capparis atamisquea) was the most abundant shrub species in both seasons. Grass and dicot forb cover decreased in relation to the very good condition site. Setaria spp. and Trichloris crinita composed most of the grass cover on the good condition range. Forbs characteristic of the lightly grazed areas, like Baccharis flexuosa and Justicia squarrosa, disappeared, whereas a tall forb unpalatable to cattle, cabrayuyo (Solanum argentinum), increased.

In the area of poor condition, Selaginella sellowii comprised most of the forage cover during the dry and wet seasons and its coverage was higher than on the good and very good condition sites (Table 1). Two thorny species (garabato, talilla) and one species unpalatable to livestock (atamisqui) made up 55\% of the total cover of shrubs. Grasses were absent and dicot forbs were rare. The percentage of bare ground cover was around $30 \%$. 


\section{Relative Abundance of Chacoan Cavies}

The relative abundance of Chacoan cavies varied depending on the range condition. Density of feces differed $(F=38.833$, d.f. $=$ $2,14, P<0.001$ ) among areas. In both seasons, the number of pellets found in the area of poor condition was higher (wet season: $x$ $=22.61 \mathrm{feces} / \mathrm{m}^{2} \pm 4.76$ (SE); dry season: $x=39.28 \pm 2.20$ ) than that for rangelands in the good (wet season: $x=1.98 \pm 1.27$; dry season: $x=9.88 \pm 2.06$ ) and the very good condition (wet season: $x=1.1 \pm 1.07$; dry season: $x=0$ ).

\section{Diet Composition}

Leaves of different kinds of forbs formed the major part of the Chacoan cavy diets regardless of range condition and season (Table 2). Similarity indices of diets when compared between seasons were higher $(85 \%)$ on the poor range site than on the very good and good condition sites (52\% and $46 \%$ respectively), indicating that consumption of plant species did not change markedly between seasons in overgrazed areas. In contrast, forage plants were not consumed in similar amounts during the wet and dry seasons on the good and very good condition rangelands. At these sites, dicot forb and grass consumption was highest during the wet season, whereas shrub and succulent ingestion increased during the dry season.

In general, the diet composition of the Chacoan cavies varied among areas of different range conditions. We found a significant change in the mean percentage of woody plants $(F=4.183, \mathrm{df}=$ $2,17, P=0.033)$, grasses $(F=15.738, \mathrm{df}=2,17, P<0.0001)$ and fruits and seeds $(F=6.959, \mathrm{df}=2,17, P=0.006)$ as diet components. The amount of forbs $(F=3.303, \mathrm{df}=2,17, P=0.0614)$ and succulents $(F=1.303, \mathrm{df}=2,17, P=0.29)$ consumed were similar for all range conditions.

The woody plant composition of the diet differed $(P<0.05)$ between the sites on the poor and very good range conditions. On the poor condition site, 2 species of shrubs, sacha limón (Capparis speciosa) and talilla, made up about $70 \%$ of the woody plant ingestion during both seasons. On the good condition site, 15 species of the woody plants were identified in the diet of the Chacoan cavy, whereas 6 species occurred on the very good condition site. Leaf fragments of the dominant trees quebracho colorado and quebracho blanco, were in trace amounts in sites of all conditions.

Although forbs consumption did not vary $(P>0.05)$ among range conditions, forb species composition was markedly different. Selaginella sellowii, the dominant plant in the diet on sites in poor condition, was a minor dietary constituent on sites in the very good and good conditions. In these areas, several species of Malvaceae and cabrayuyo were the major herbaceous dietary components.

Chacoan cavies consume grasses when available, but we did not find differences $(P>0.05)$ between the sites in the good and very good range conditions. On the good range condition site, about $32.5 \%$ of the diet was composed of grasses during the wet season. At this site, Setaria spp. were the most frequent grasses found in the diet. On the very good condition site, grasses made up $20 \%$ of the diet (Table 2) despite its high availability (70\%) on the range (Table 1). Important species in the diet included (Gouinia sp., Paspallum villosum and Trichloris crinita. Grasses were absent in the diet of Chacoan cavies that fed on the poor condition area.
Table 2. Seasonal variation in the mean percentages $( \pm$ SD) of food items found in the Chacoan cavy diet according to range condition in the Western Chaco, Argentina.

\begin{tabular}{|c|c|c|c|c|c|c|}
\hline & \multicolumn{2}{|c|}{ Very good } & \multicolumn{2}{|c|}{ Good } & \multicolumn{2}{|c|}{ Poor } \\
\hline & Wet & $\overrightarrow{\text { Dry }}$ & Wet & Dry & Wet & Dry \\
\hline Woody Plants & $\cdots$ & 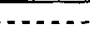 & $-\ldots$ & $\%)-. .-$ & $\ldots \ldots$ & $\ldots$ \\
\hline Garabato & $\begin{array}{c}3.1 \\
( \pm 1.0)\end{array}$ & $\begin{array}{c}1.4 \\
( \pm 0.5)\end{array}$ & $\begin{array}{c}2.6 \\
( \pm 1.6)\end{array}$ & $\begin{array}{c}3.0 \\
(+1.7)\end{array}$ & $\begin{array}{c}4.7 \\
(+2.3)\end{array}$ & $\begin{array}{r}2.6 \\
( \pm 1.2)\end{array}$ \\
\hline $\begin{array}{l}\text { Palo matico } \\
\text { (Achatocarpus } \\
\text { praecox) }\end{array}$ & $\mathrm{T}$ & $\begin{array}{c}3.5 \\
(+1.2)\end{array}$ & $\mathrm{T}$ & $\begin{array}{c}1.1 \\
(+1.2)\end{array}$ & 0 & 0 \\
\hline $\begin{array}{l}\text { Quebracho } \\
\text { blanco }\end{array}$ & 0 & $\mathrm{~T}$ & 0 & $\begin{array}{r}4.9 \\
( \pm 4.0)\end{array}$ & $\mathrm{T}$ & $\mathrm{T}$ \\
\hline Sacha limón & $\begin{array}{r}1.0 \\
( \pm 1.3)\end{array}$ & $T$ & $\mathrm{~T}$ & $\begin{array}{c}1.7 \\
( \pm 2.0)\end{array}$ & $\begin{array}{r}18.6 \\
( \pm 2.4)\end{array}$ & $\begin{array}{c}18.9 \\
( \pm 3.6)\end{array}$ \\
\hline Talilla & $\mathrm{T}$ & $\begin{array}{c}1.9 \\
( \pm 0.5)\end{array}$ & 0 & $\begin{array}{r}1.4 \\
( \pm 0.4)\end{array}$ & $\begin{array}{r}7.1 \\
(+2.4)\end{array}$ & $\begin{array}{r}6.2 \\
( \pm 2.4)\end{array}$ \\
\hline $\begin{array}{l}\text { Abreboca } \\
\text { (Maytenus spinosa) }\end{array}$ & 0 & $\begin{array}{c}0 \\
( \pm 1.9)\end{array}$ & $\begin{array}{c}1.3 \\
( \pm 0.9)\end{array}$ & 1.0 & $\mathrm{~T}$ & $\begin{array}{c}1.3 \\
( \pm 2.1)\end{array}$ \\
\hline Sinqui & $\mathrm{T}$ & $\mathrm{T}$ & $\begin{array}{c}2.0 \\
( \pm 0.8)\end{array}$ & $\begin{array}{r}2.9 \\
( \pm 1.9)\end{array}$ & $\mathrm{T}$ & $\mathrm{T}$ \\
\hline $\begin{array}{l}\text { Quiscataco } \\
\text { (Prosopis elata) }\end{array}$ & $\begin{array}{c}5.3 \\
( \pm 0.7)\end{array}$ & $\begin{array}{c}1.3 \\
( \pm 0.2)\end{array}$ & $\begin{array}{c}2.3 \\
( \pm 2.6)\end{array}$ & $\begin{array}{r}9.0 \\
(+5.5)\end{array}$ & $\begin{array}{c}0.9 \\
(+0.9)\end{array}$ & $\begin{array}{r}2.3 \\
( \pm 2.9)\end{array}$ \\
\hline $\begin{array}{l}\text { Algarrobo ncgro } \\
\text { (Prosopis nigra) }\end{array}$ & $\begin{array}{r}1.4 \\
(+0.5)\end{array}$ & $\begin{array}{r}1.2 \\
( \pm 1.1)\end{array}$ & $\mathbf{T}$ & $\begin{array}{r}5.2 \\
( \pm 0.8)\end{array}$ & $\mathrm{T}$ & $\mathrm{T}$ \\
\hline $\begin{array}{l}\text { Tintitaco } \\
\text { (Prosopis torquata) }\end{array}$ & $\mathrm{T}$ & $\mathrm{T}$ & $\mathrm{T}$ & $\begin{array}{r}6.2 \\
( \pm 4.1)\end{array}$ & $\mathrm{T}$ & $\mathrm{T}$ \\
\hline Others & $\begin{array}{c}0.4 \\
( \pm 0.1)\end{array}$ & $\begin{array}{r}2.2 \\
( \pm 1.2)\end{array}$ & $\begin{array}{r}2.3 \\
(+1.9)\end{array}$ & $\begin{array}{r}8.9 \\
( \pm 2.6)\end{array}$ & $\begin{array}{c}1.0 \\
( \pm 0.6)\end{array}$ & $\begin{array}{r}1.5 \\
( \pm 1.4)\end{array}$ \\
\hline $\begin{array}{l}\text { Total woody } \\
\text { plants }\end{array}$ & $\begin{array}{c}15.3 \\
( \pm 0.8)\end{array}$ & $\begin{array}{c}24.1 \\
( \pm 0.3)\end{array}$ & $\begin{array}{c}15.3 \\
( \pm 6.3)\end{array}$ & $\begin{array}{r}47.8 \\
( \pm 12.1)\end{array}$ & $\begin{array}{l}36.6 \\
( \pm 2.4)\end{array}$ & $\begin{array}{c}37.5 \\
( \pm 1.8)\end{array}$ \\
\hline
\end{tabular}

Forbs

Dyschoristes

2.3
venturii $( \pm 2.4)$

Justicia squarrosa

$( \pm 2.4)$
2.6

$(+3.4)$

Malvaceae

13.8

$( \pm 15.5)$

Rivinia humilis

0

Selaginella sellowi

7.1

$(+3.9)$

Solanum

chacoensis

2.8

( +3.1$)$

Cabrayuyo

Others

Total forbs

6.0
$( \pm 7.1)$

10.8

$( \pm 7.0)$

$$
0
$$

1.0

1.0
$(1.4)$

8.4
$+2.9)$

0

2.2

(44.4)

$$
0
$$

0

o

17.2

120

$$
0
$$

0

(43.1)

( 7.9$)$

$3.8 \quad 2.6$

$(44.0)$

$(+1.7)$

8.2

(+8.9)

3.2

$(44.1)$

1.5
$(+2.2)$

1.0
$( \pm 1.4)$

7.7

$( \pm 10.7)$

3.1

3.1
$( \pm 0.8)$

$49.4 \quad 31.2$

$( \pm 8.5) \quad( \pm 27.5)$

4.6

4.6
$(4.2)$

16.2

$( \pm 4.2)$

45.3

$( \pm 5.9)$

1.5

$\frac{\text { Grasses }}{\text { Aristida }}$

mendacina

$( \pm 0.7)$

Gouinia sp.

7.4

$( \pm 2.4)$

Paspallum villosum 4.6

$(+0.6)$

Setaria spp.

1.3

$( \pm 1.5)$

Trichloris crinita

2.8

$( \pm 3.5)$

Others

2.0

$( \pm 2.8)$

Total grasses

20.0

$( \pm 6.1)$

Succulents

T

Fruits_and Seeds

12.8

$( \pm 2.5)$

$\mathrm{T}=$ Trace species
1.6

2.6

$( \pm 0.3) \quad( \pm 1.6)$

$$
\mathrm{T}
$$

T

$\mathrm{T}$

2.2

$( \pm 2.0)$

16.2

$( \pm 6.5)$

T

$( \pm 2.0)$

6.4

$( \pm 5.7)$

102

9.7

$(+5.3)$

$32.5 \quad 9.5$

$( \pm 4.9)$

$\pm 14.0$

$(+9.1)$

T $\quad \begin{array}{r}6.7 \\ ( \pm 6.3)\end{array}$

$\begin{array}{rr}6.4 & 2.4 \\ (+4.8) & (+2.2)\end{array}$

$( \pm 7.8) \quad( \pm 4.8)$

$( \pm 2.2)$

$( \pm 1.0)$

10.2
$( \pm 3.3)$

$4.2 \quad 0.9$

$\begin{array}{rr}4.1 & 0.9 \\ (+3.1) & (+0.8)\end{array}$ 


\section{Discussion}

Our study confirms the relationship of rodent and rabbit abundance to deterioration of rangeland that has been well-studied in the western United States and elsewhere. Lindsdale (1946) noted the disappearance of jackrabbits (Lepus) and ground squirrels (Citellus) from a California oak savanna following protection from livestock grazing. Reynolds (1956) has noted the relationship between the abundance of kangaroo rats (Dipodomys sp.) and the condition of the range as influenced by domestic stock. Similarly, Fogden (1978) found in northern Mexico that the rangeland parameters correlated with high jackrabbit densities were symptoms of rangeland in poor condition. In Argentina, Kufner and Chambouleyron (1991) found a similar tendency in maras (Dolichotis patagonum) when comparing densities in a reserve of the Monte region and surround areas subjected to cattle grazing.

Some long term studies have demonstrated that rodents and lagomorph have profound impacts upon native vegetation and on ecosystem processes, preventing the improvement of deteriorated arid rangelands. Brown and Heske (1990) found that the effects on vegetation of the exclusion of a rodent guilds in combination with livestock exclusion were much greater than those produced by the exclusion of livestock. Gibbens et al. (1993) also showed that preferential grazing by lagomorph can influence the species composition of shrub, suffrutescent and perennial grass cover. The low density or lack of Chacoan cavies found in rangelands of good and very good conditions permit us to suggest that the Chacoan cavy should be considered as an indicator of vegetation depletion caused by other factors rather than a primary cause of savanna degradation. It must be recognized, however, that in deteriorated rangelands high densities of this species and other rodents, particularly the vizcacha (Lagostomus maximus), may prevent the Chaco vegetation from recovery even aftcr complete exclusion of cattle and goats (Saravia Toledo 1987).

The dietary composition of the Chacoan cavy was greatly influenced by the amount of forage available, which varied depending on the condition of the rangeland. They consumed a greater number of species in areas of very good and good conditions than when feeding on the poor condition rangelands. When the forage resource was limited by livestock grazing or drought, their diet included just a few food items that were abundant on the range. Kufner and Pelliza Sbriller (1987) found that maras changed their diet significantly from forbs to grasses after forb coverage was reduced by cattle grazing. Consumption of various components of the herbaceous category varied greatly from season to season. The use of grasses was highly seasonal, given that availability to the green grass was mostly limited to the wet season. Annual forbs (e.g. species of Malvaceae) are particularly important as forage because they are available throughout the wet season and early dry season. Leaves from large forb species undesirable to cattle were consumed during the stressed period. Our data provide no evidence for a significant impact of Chacoan cavies on the seedlings of hardwood trees. Although woody plants were heavily used during the dry season in all range conditions, leaf fragment frequency of the seedlings of dominant trees was low in the Chacoan cavy feces. However, visual observations confirm that these plants are sometimes severely damaged by girdling (Bucher 1982, Saravia Toledo 1987). Although this needs further study, we think that in overgrazed areas and in years with a long drought period, this rodent may cause damage to the young trees.

The wide variation in the abundance of Chacoan cavies reported here confirms that this rodent has specific habitat requirements associated with range condition. Our results suggest that at least 2 factors may explain the observed pattern of abundance. First, the changes in food availability resulting from variations in plant species composition associated with grazing pressure. The second factor may be related to structural characteristics of the habitat (Rosati and Bucher, unpubl. data). Factors associated with habitat selection, such as preferences for open spaces to minimize risk of predation may also play an important role in determining the distribution of Chacoan cavies in the Western Chaco. Therefore the fact that high densities of Chacoan cavies were found on the poor range condition site raises the possibility of developing management practices through habitat manipulation.

\section{Literature Cited}

Brown, J.H., and E.J. Heske. 1990. Control of a Desert-Grassland transition by a keystone rodent guild. Sci. 250:1705-1707.

Bucher, E.H. 1982. Chaco and Caatinga-South American arid savannas, woodlands and thickets. In: Huntley B.\&B. Walkers (eds.). Ecology of Tropical Savannas: 47-49. Springer Verlag, Berlin.

Cabrera, A., and J. Yepes. 1940. Mamfferos Sudamericanos. Cia. Argentina de Editores. Buenos Aires.

Fogden, M.L.P. 1978. The impact of lagomorph and rodents on the cattle rangelands of northern Mexico. Center for overseas. Pest research. London. Rep. 1973-1977.

Galmarini, A., and J. Raffo del Campo. 1964. Rasgos fundamentales que caracterizan al clima de la región chaqueña. CONADE. Publicación $\mathrm{N}^{\circ} 9.178 \mathrm{pp}$.

Gibbens, R.P., K.H. Havstad, D.D. Billheimer, and C.H. Herbel. 1993. Creosotebush vegetation after 50 years of lagomorph exclusion. Oecologia 94:210-217.

Hansen, R.M., A.S. Moir, and S.R. Woodmansee. 1971. Drawing tissues of plants found in herbivore diets and in the litter of grasslands. Colorado State Univ. Range Sci. Dep., Tech. Rep., 70:1-69.

Holechek, J.L., and B.D. Gross. 1982. Evaluation of different calculation procedures for microhistological analysis. J. Range Manage. 35:721-723.

Johnson, M.K., H. Wofford, and H.E. Pearson. 1983. Microhistological techniques for food habits analysis. Res. Pap. SO199. USDA and Forest Serv. $40 \mathrm{pp}$.

Kufner, M.B., and A. Pelliza Sbriller. 1987. Composición botánica de la dieta del mara (Dolichotis patagonum) y del ganado bovino en el Monte mendocino. Revista Argentina de Producción Animal 7:255-264.

Kufner, M.B., and M. Chambouleyron. 1991. Actividad espacial de Dolichotis patagonum en relación a la estructura de la vegetación en el Monte argentino. Studies on Neotropical Fauna and Environment 26:249-255.

Lindsdale, J.M. 1946. The California Ground Squirrel. University of California Press. Berkeley.

Litvaitis, J.A., J.A. Sherburne, and J.A. Bissonette. 1985. A comparison of methods used to examine snowshoe hare habitat use. J. Wildl. Manage. 49:693-695.

Mares, M.A., R.A. Ojeda, and R.M. Barquez. 1989. Guide to the mammals of Salta Province, Argentina. Guía de los mamíferos de la provincia de Salta, Argentina. Univ. Oklahoma. Press, Norman, Okla.

Morello, J., and C. Saravia Toledo. 1959. El Bosque chaqueño I. Paisaje primitivo, paisaje natural y paisaje cultural en el oriente de Salta. Revista Agronómica del Noroeste Argentino 3:5-81.

Oosting, H.J. 1956. The study of plant communities. 2nd ed. W.H. Freeman and Co., San Francisco, Calif.

Reynolds, H. 1956. The ecology of the Merriam kangaroo rat (Dipodomys merriami Mearns) on the grazing land of southern Arizona. Ecol. Monogr. 28:111-127. 
Rosati, V.R. 1991. Caracteres epidérmicos foliares de valor diagnóstico en la identificación de plantas lenosas del Chaco occidental. Agriscientia VIII: 41-53.

Rosati, V.R., and E.H. Bucher. 1992. Seasonal diet of Chacoan cavy (Pediolagus salinicola) in the westem Chaco, Argentina. Mammalia 56:567-574.

Saravia Toledo, C. 1987. Restoration of degraded pastures in the semiarid Chaco region of Argentina: 25-37. In: Proceedings International Symposium on Ecosystem Redevelopment: Ecological, Economic, and Social Aspects, April 1987. UNESCO. Budapest.

Sarmiento, G. 1972. Ecological and floristic convergences between seasonal plant formations of tropical and subtropical South America. J. Ecol. 60:367-410.
Sparks, D.R., and J.C. Malechek. 1968. Estimating percentage dry weight in diets using a microscope technique. J. Range Manage. 21:264-265.

USDA Forest Service. 1970. Range environmental analysis handbook. FSH 2209.21R3. Region 3, Albuquerque, N.M.

Williams, O.B. 1969. An improved technique for identification of plant fragments in herbivore feces. J. Range Manage. 22:51-52.

Zar, J.H. 1984. Biostatistical analysis. Second edition. Prentice-Hall, Inc., Englewood, Cliffs, N.J.

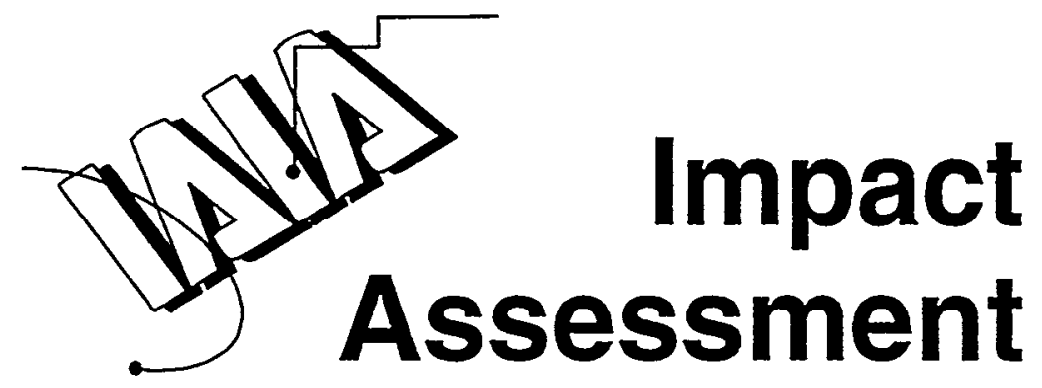

The Quarterly Journal of the International Association for Impact Assessment

Impact Assessment is an international, multidisciplinary, peerreviewed journal publishing articles of original research and professional practice in the fields of impact assessment: environmental impact assessment (EIA), risk assessment (RA), social impact assessment (SIA), technology assessment (TA), and other forms of impact assessment.

Impact Assessment is edited by Daniel Bronstein, managing editor, Department of Resource Development, Michigan State University, 302 Natural Resources Bldg., East Lansing, Michigan 48824 USA. John Page, Parsons Brinckerhoff, 4000 WestChase Blvd., Raleigh, North Carolina 27607 USA, is the professional practices editor.

Annual Subscription Rate (U.S.\$)

Individual subscriber

institutional/tibrary

Optronal aumail outside

North America add
Send order with payment to

Rita Hamm, Exec. Dir.

P.O. Box 5256

Fargo, ND 58105-5256 USA

(701) 231-1006

\section{Order Form}

ProtTypo Niate Tige

Postacose

